\title{
BMJ Open Self-rated health among migrants from the former Soviet Union in Germany: a cross-sectional study
}

\author{
Susanne Stolpe, ${ }^{1,2}$ Mary Ouma, ${ }^{3}$ Volker Winkler, ${ }^{3}$ Christa Meisinger, ${ }^{4}$ \\ Heiko Becher, ${ }^{3,5}$ Andreas Deckert ${ }^{6}$
}

To cite: Stolpe S, Ouma M, Winkler V, et al. Self-rated health among migrants from the former Soviet Union in Germany: a crosssectional study. BMJ Open 2018;8:e022947. doi:10.1136/ bmjopen-2018-022947

- Prepublication history and additional material for this paper are available online. To view please visit the journal (http:// dx.doi.org/10.1136/bmjopen2018-022947).

Received 19 March 2018 Revised 5 July 2018 Accepted 18 September 2018

Check for updates

(c) Author(s) (or their employer(s)) 2018. Re-use permitted under CC BY-NC. No commercial re-use. See rights and permissions. Published by BMJ.

For numbered affiliations see end of article.

Correspondence to

Susanne Stolpe;

susanne.stolpe@uk-essen.de

\section{ABSTRACT}

Objectives To assess the status and change in self-rated health among Aussiedler, ethnic German immigrants from the former Soviet Union, as a predictor for premature death 10 years after first assessment. Moreover, to identify subgroups which are particular at risk of anticipated severe health impairment.

Design Cross-sectional questionnaire.

Setting The study was conducted in the catchment area of Augsburg, a city in southern Bavaria, Germany, in 2011/2012 that has a large community of Aussiedler. Participants 595 Aussiedler (231 male, 364 female, mean age 55 years) who in majority migrated to Germany between 1990 and 1999.

Outcome Primary outcome: self-rated health (very $\mathrm{good} / \mathrm{good} / \mathrm{not}$ so good/bad) and its association with demographic, social and morbidity related variables. Methods Self-rated health was dichotomised as 'very good' and 'good' versus 'not so good' and 'bad'. Multivariable logistic models were created. Missing values with regard to pain were addressed by a second analysis. Results Although low response suggests a healthier sample, the findings are alarming. Altogether $47 \%$ of the Aussiedler perceived their health as less than good, which is worse compared with the first assessment in 2000 (25\% compared with $20 \%$ of the general public). Prevalence of high blood pressure was present in $52 \%$ of Aussiedler, $34.5 \%$ were obese, $40.7 \%$ suffered from frequent pain and $13.1 \%$ had diabetes mellitus. According to the multivariable models, individuals suffering from pain, limited mobility, diabetes mellitus and high blood pressure are particularly in jeopardy.

Conclusions 10 years after the first assessment of selfrated health among Aussiedler their situation deteriorated. Tailored risk factor counselling of general practitioners is highly recommended.

\section{INTRODUCTION}

The migration process of Aussiedler (ethnic German resettlers) to Germany is unique all around the world. The Aussiedler have to be distinguished from other migrants, as they officially are not regarded and registered as foreigners by law. Aussiedler are of German ancestry, settling in eastern European countries since the 17th century, on invitation of

\section{Strengths and limitations of this study}

- Aussiedler are a subgroup of the German population that is hard to convince to take part in any survey as they often mistrust any official questioning due to their experiences in their home countries.

- In our study, especially great effort was set into recruiting participants; it can be assumed that so far this is the largest questionnaire study in this German subpopulation.

- The detailed bilingual questionnaire comprised items singularly tailored to this population.

- Aussiedler who took part in the study mostly answered the questionnaire completely, however, few items had a larger portion (13\%) of missing data.

- Besides the limitations due to the cross-sectional design, the low response rate implies a highly selected and healthier subgroup of the Aussiedler population, indicating our results to be even more alarming.

the Russian emperor, and benefiting from many politically granted privileges for many decades. However, the steadily destabilising political situation in Russia in the early 20th century peaked with the deportation and banishment of the entire German settler population during World War II. Although their situation in the Soviet Union slowly improved subsequent to the demise of Stalin, all political efforts to fully redeem the legal status of the German communities in Russia failed. The recrudescence of persecution of ethnic minorities, as in Kazakhstan in 1986, strengthened their desire to emigrate 'back home' to Germany. When the new law on emigration and immigration in the Soviet Union entered into force in 1987, many seized the opportunity and a mass emigration of ethnic Germans started. Since the collapse of the Soviet Union more than 2 million Aussiedler and their families migrated from the Former Soviet Union (FSU) to Germany. In the early 1990s, Aussiedler were attracted by many privileges such 
as immediate entitlement to pension for retired Aussiedler, language courses paid for by the government and professional job-seeking assistance. Aussiedler and their family members automatically received German citizenship. Nevertheless, in daily life their identity and affiliation was often questioned by native Germans, calling them 'Russians'.

Epidemiological studies on Aussiedler found a significantly lower overall and cardiovascular diseases (CVD) mortality, but a significantly increased myocardial infarction incidence in men. ${ }^{2-5}$ Findings of migration studies are prone to be biased due to the so-called healthy migrant effect, which assumes that preferably younger and healthier individuals escape bad living conditions, resulting in health advantages of the migrant study population compared with the autochthonous population of the host country. ${ }^{2}$ However, the healthy migrant effect most probably is non-existent in Aussiedler, since their immigration was politically encouraged and came along with many privileges, forcing entire families to emigrate. Moreover, age at arrival of some individuals was quite high, and several individuals died of severe diseases in the transition accommodations within 1 year after arrival. ${ }^{2}$

An analysis of CVD risk factors among Aussiedler revealed a lower prevalence of alcohol consumption compared with the German population. ${ }^{6}$ However, cardiometabolic risk factors are more prevalent among Aussiedler. $^{6-8}$ Cancer incidence and mortality show site-specific differences in cancer in comparison to the German population and confirm the different risk profile of Aussiedler. ${ }^{9}{ }^{10}$ Further research revealed high suicide mortality among Aussiedler immigrating in their youth, which probably relates to integration problems. ${ }^{10}$ Hence, despite the historically significantly lower overall and CVD mortality, recent findings suggest impaired health of Aussiedler in Germany. A universal measure such as self-rated health, covering the biological constitution as well as environmental living conditions and psychosocial well-being, may help to assess the health situation of the Aussiedler.

Aparicio et al. compared self-rated health of ethnic German immigrants from different Eastern European origins and the general German population in Augsburg region in 2000 and found a significantly higher frequency of poor self-rated health among the immigrants, accompanied by higher prevalence of obesity, hyperlipidemia and lack of physical activity, with the effects shrinking with increasing length of stay. Aussiedler from FSU constituted $73 \%$ of the study population, hence can be considered as vulnerable population in terms of being at higher risk of severely falling ill during their life course compared with the general population. ${ }^{7}$

The objectives of this article are: (1) to determine the self-rated health of Aussiedler around 10 years after the investigation by Aparicio et al., (2) to describe the differences to the findings of Aparicio et al., and (3) to identify variables independently related to self-rated health.

\section{METHODS}

The presented study complies with the Declaration of Helsinki; the ethics committee of the medical association of Bavaria has approved the research. Out of 685 completed questionnaires, written informed consent or information on sex was missing in 90 cases, which have been excluded from the analyses.

\section{Data sources, study population and public involvement}

Significant differences in overall and cause-specific mortality between the ethnic German immigrants and the general population based on register data required the investigation of differences in lifestyle and other determinants of diseases. The cross-sectional study among Aussiedler in Augsburg was conducted in 2011 and 2012, using the infrastructure and expertise of the KORA (COoperative health Research in the Augsburg region) study centre. A full sample of all Aussiedler residents $(\mathrm{n}=6378)$ was available, who immigrated to Augsburg region after 1990 and were still resident there in 2010. This was obtained from a resident registration reconciliation. After excluding individuals younger than 15 years of age at time of immigration the final study population's size was $\mathrm{n}=3718$. A bilingual German-Russian questionnaire, based on the validated KORA study questionnaire was adapted. ${ }^{11}$ The questionnaire contained 42 items, including questions on lifestyle, immigration background, morbidity, mental health and access to healthcare.

The project was then presented and discussed in two meetings with representatives of the city of Augsburg, the local politicians, physicians and representatives of the ethnic immigrants. The questionnaire and study information material was adjusted according to their recommendations and concerns. Afterwards, the questionnaire was tested in two pilot phases on two randomly chosen subsets (altogether $n=280$ ) of the study population and the accompanying material (eg. information sheet) was further adjusted. The data of the pilot phases were included in the analyses.

Two travels of a researcher of Heidelberg University were used to personally promote the study in the Aussiedler community and discuss open questions. Researchers from Heidelberg University personally promoted the study in the Aussiedler community twice and discussed open questions. A prominent association of the ethnic German immigrants supported the recruitment with articles in their supra-regional newspaper and announced the study during an official annual festivity. Moreover, we placed advertisements in local newspapers calling for study participation. Several shops, physicians, restaurants, pharmacies, educational institutions, etc. provided flyers and posters. Then the questionnaire was sent out to the remaining study population. The questionnaire was disseminated via mail, online media (Odnoklassniki) and medical practices. The delivered materials comprised a study leaflet, introductory letter, the bilingual questionnaire including informed consent and a letter of support of the head of the local Aussiedler 


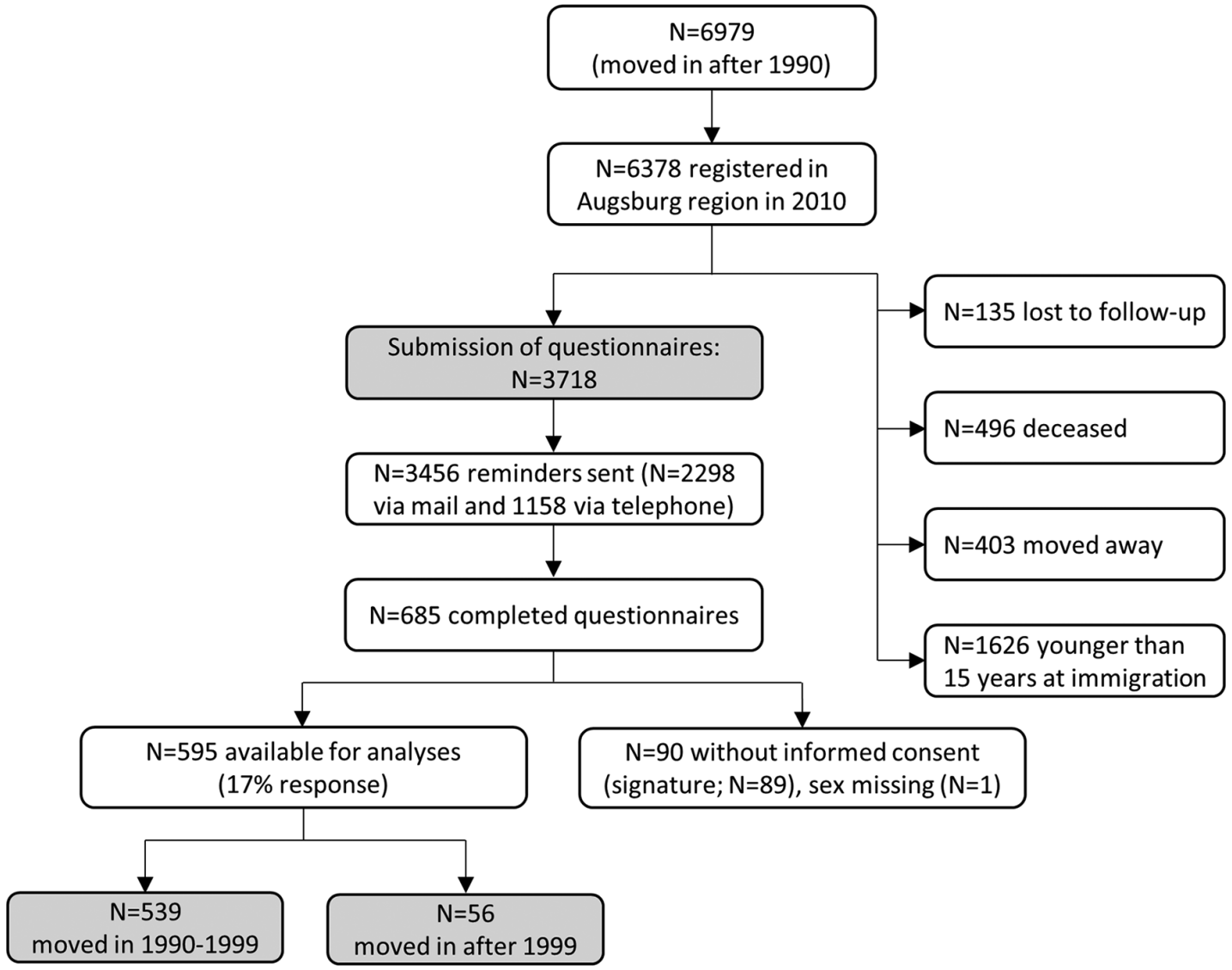

Figure 1 Study recruitment flow chart.

organisation. Reminders were sent to non-respondents and when possible contacted by telephone to motivate response. Owing to the low response rate, the study information material and recruitment procedures were altered and adjusted several times. For instance, bilingual personnel in medical practices assisted in the completion of the questionnaire, telephone hotlines were set up and potential participants were visited at home. Concerns and recommendations of study participants were considered in further recruitment approaches. The flowchart of the study participants' recruitment is shown in figure 1 .

We consented to inform the association of the ethnic German immigrants about the dissemination of the study results and will report the findings in the association's supra-regional newspaper.

\section{Statistical analysis}

Statistical analyses were performed in SAS V.9.3. Descriptive differences between sexes in the socio-demographic, immigration and health related characteristics were tested by means of a $\mathrm{X}^{2}$ test. If a category of a categorical variable contained only few observations, the concerning category was combined with the subsequent category. The study-relevant outcome selfrated health was queried by the item 'How would you describe your health status in general?' Subsequently, self-rated health was dichotomised according to the WHO (1996) and the EURO-REVES 2 group ${ }^{12}$ as 'very good', 'good' versus 'not so good' and 'bad'. Single associations between the explanatory variables and the dichotomised self-rated health were investigated by age-adjusted and sex-adjusted ORs.

In order to model the associations between multiple explanatory variables and self-rated health, we considered socio-demographic items and items related to migration history and the immigration process, as well as items reflecting the status of societal integration and stress factors, based on theoretical health concepts such as the life course concept and the social network theory. ${ }^{13-15}$ We completed the list of explanatory variables with items that directly relate to health, for instance self-reported morbidity. In order to create the final model, a backward selection algorithm based on a significance level of $10 \%$ was applied, aiming to maximise the explained variance. To evaluate the goodness-of-fit of the logistic models, we used McFadden's Pseudo R², since classical $\mathrm{R}^{2}$ statistics are not applicable with maximum likelihood estimates. Pseudo $\mathrm{R}^{2}$ is a valid tool to evaluate multiple models predicting the same outcome and on the same data set. $^{16} 17$

Age at immigration was omitted in the multivariable modelling due to its high correlation with current age (Spearman's rank correlation coefficient 0.92). Due to the high number of missing values $(\mathrm{n}=75,12.6 \%)$, frequency of pain (never, rarely, often, always) was excluded from 
model I. However, with regard to self-rated health, pain is an important variable, not highly correlated with other variables though. Hence, we set up an additional more conservative model II where all missings in the variable 'frequency of pain' were replaced by 'never'. In model II, 'education' was eliminated by the backward selection algorithm.

\section{RESULTS}

Table 1 displays the socio-demographic characteristics of the participants, stratified by sex. Participants were predominantly female $(61.2 \%)$, with an overall mean age of 55.4 years (median: 56 years) at time of the interview (range 19-93 years). Majority of Aussiedler did not live alone. Gender showed a significant association with

Table 1 Socio-demographic characteristics of the study population

\begin{tabular}{|c|c|c|c|c|c|c|c|}
\hline & \multicolumn{2}{|c|}{ Total } & \multicolumn{2}{|l|}{ Men } & \multicolumn{2}{|c|}{ Women } & \multirow[b]{2}{*}{$P$ values } \\
\hline & $\mathbf{N}$ & $\%$ & $\mathbf{N}$ & $\%$ & $\mathbf{N}$ & $\%$ & \\
\hline & 595 & 100.0 & 231 & 38.8 & 364 & 61.2 & 0.5 \\
\hline Age & & & & & & & 0.9 \\
\hline 11-20years & 3 & 0.5 & 1 & 0.4 & 2 & 0.6 & \\
\hline $21-30$ years & 11 & 1.9 & 5 & 2.2 & 6 & 1.7 & \\
\hline $31-40$ years & 79 & 13.5 & 27 & 11.9 & 52 & 14.5 & \\
\hline $41-50$ years & 120 & 20.5 & 44 & 19.4 & 76 & 21.2 & \\
\hline $51-60$ years & 170 & 29.0 & 66 & 29.1 & 104 & 29.0 & \\
\hline $61-70$ years & 112 & 19.1 & 46 & 20.3 & 66 & 18.4 & \\
\hline $71-80$ years & 69 & 11.8 & 31 & 13.7 & 38 & 10.6 & \\
\hline$\geq 81$ years & 22 & 3.8 & 7 & 3.1 & 15 & 4.2 & \\
\hline Missing* & 9 & 1.5 & 4 & 1.7 & 5 & 1.4 & \\
\hline Family size & & & & & & & 0.2 \\
\hline Single & 87 & 14.8 & 26 & 11.4 & 61 & 16.9 & \\
\hline Two persons & 269 & 45.6 & 110 & 48.0 & 159 & 44.0 & \\
\hline Three or more persons & 234 & 39.7 & 93 & 40.6 & 141 & 39.7 & \\
\hline Missing* & 5 & 0.8 & 2 & 0.9 & 3 & 0.8 & \\
\hline Marital status & & & & & & & $<0.001$ \\
\hline Married & 446 & 75.3 & 196 & 85.6 & 250 & 68.9 & \\
\hline Single & 33 & 5.6 & 9 & 3.9 & 24 & 6.6 & \\
\hline Divorced/widowed & 113 & 19.1 & 24 & 10.5 & 89 & 24.5 & \\
\hline Missing ${ }^{*}$ & 3 & 0.5 & 2 & 0.9 & 1 & 0.3 & \\
\hline Education level & & & & & & & 0.5 \\
\hline No education & 33 & 5.7 & 13 & 5.7 & 20 & 5.6 & \\
\hline $\begin{array}{l}\text { Still studying/secondary } \\
\text { school/vocational study }\end{array}$ & 283 & 48.5 & 114 & 50.0 & 169 & 47.6 & \\
\hline Upper secondary school & 128 & 22.0 & 47 & 20.6 & 81 & 22.8 & \\
\hline University & 126 & 21.6 & 46 & 20.2 & 80 & 22.5 & \\
\hline Other & 13 & 2.2 & 8 & 3.5 & 5 & 1.4 & \\
\hline Missing ${ }^{*}$ & 12 & 2.0 & 3 & 1.3 & 9 & 2.5 & \\
\hline Labour situation & & & & & & & $<0.001$ \\
\hline Full-time & 229 & 38.6 & 134 & 58.0 & 95 & 26.2 & \\
\hline Part time & 86 & 14.5 & 4 & 1.7 & 82 & 22.7 & \\
\hline Others & 81 & 13.7 & 20 & 8.7 & 61 & 16.9 & \\
\hline Unemployed & 45 & 7.6 & 13 & 5.6 & 32 & 7.6 & \\
\hline Retired & 152 & 25.6 & 60 & 26.0 & 92 & 25.4 & \\
\hline Missing* & 2 & 0.3 & - & - & 2 & 0.5 & \\
\hline
\end{tabular}

${ }^{*}$ Number of missing in relation to $n=595$ (not part of the categories). 
Table 2 Life course and integration-related characteristics of the study population

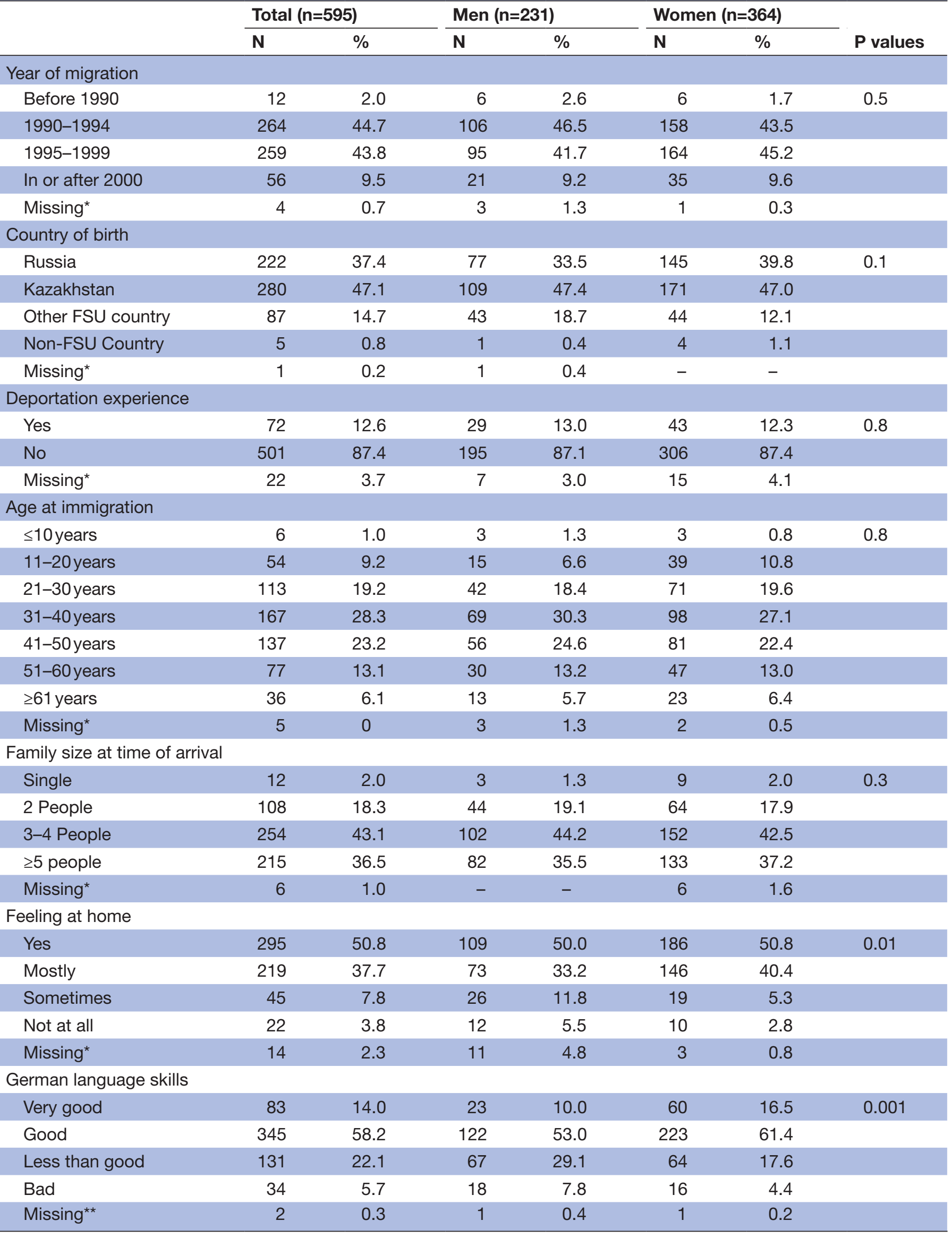


Table 2 Continued

\begin{tabular}{|c|c|c|c|c|c|c|c|}
\hline & \multicolumn{2}{|c|}{ Total $(n=595)$} & \multicolumn{2}{|c|}{ Men $(n=231)$} & \multicolumn{2}{|c|}{ Women $(n=364)$} & \multirow[b]{2}{*}{$P$ values } \\
\hline & $\mathbf{N}$ & $\%$ & $\mathbf{N}$ & $\%$ & $\mathbf{N}$ & $\%$ & \\
\hline \multicolumn{8}{|l|}{ Smoking } \\
\hline Never & 376 & 64.5 & 76 & 33.3 & 300 & 84.5 & $<0.001$ \\
\hline Stopped smoking & 116 & 19.9 & 88 & 38.6 & 28 & 7.9 & \\
\hline $\begin{array}{l}\text { Less than } 10 \text { cigarettes per } \\
\text { day }\end{array}$ & 37 & 6.4 & 20 & 8.8 & 17 & 4.8 & \\
\hline $\begin{array}{l}10 \text { or more cigarettes per } \\
\text { day }\end{array}$ & 54 & 9.3 & 44 & 19.3 & 10 & 2.8 & \\
\hline Missing * & 12 & 2.0 & 3 & 1.3 & 9 & 2.5 & \\
\hline \multicolumn{8}{|l|}{ Alcohol } \\
\hline Never & 63 & 11.2 & 7 & 3.2 & 56 & 16.4 & $<0.001$ \\
\hline Stopped drinking & 60 & 10.7 & 27 & 12.3 & 33 & 9.7 & \\
\hline Drinking alcohol & 438 & 78.1 & 185 & 84.5 & 253 & 74.0 & \\
\hline Missing * & 34 & 5.7 & 12 & 5.2 & 22 & 6.0 & \\
\hline \multicolumn{8}{|l|}{ Self-rated health } \\
\hline Very good & 29 & 4.9 & 6 & 2.6 & 23 & 6.4 & 0.1 \\
\hline Good & 282 & 47.6 & 119 & 51.7 & 163 & 45.0 & \\
\hline Less than good & 239 & 40.4 & 92 & 40.0 & 147 & 40.6 & \\
\hline Bad & 42 & 7.1 & 13 & 5.7 & 29 & 8.0 & \\
\hline Missing ${ }^{*}$ & 3 & 0.5 & 1 & 0.4 & 2 & 0.5 & \\
\hline
\end{tabular}

*Number of missing in relation to $n=595$ (not part of the categories).

marital status: men were $85.6 \%$ more likely to be married as compared with $68.9 \%$ of women. In addition, $58 \%$ of the men were full-time employed, compared with $41.5 \%$ of the women. The unemployment rate was $5.6 \%$ among men and $8.8 \%$ in women. Nearly every second participant $(47.6 \%)$ had graduated from school with a qualification for higher education.

Characteristics of the study population related to immigration are shown in table 2. About half of the participants resettled in Germany between 1990 and 1995 after the collapse of the Soviet Union. Majority of the Aussiedler came from Kazakhstan, followed by Russia. About $15.8 \%$ of Aussiedler reported having experienced prior mass deportation within or right after World War II. Mean age at arrival in Germany was 38.6 years (median: 39) and highly correlated with current age $(\mathrm{r}=0.94)$. Three-quarters of all immigrants were accompanied by three or more family members.

Only $11.3 \%$ of the participants partly or not at all felt at home in Germany, with men significantly feeling less at home. German language skills were good or very good among $72 \%$ of the study population, while women reported significantly better language skills.

When asked how the respondents self-rated their health, every second Aussiedler classified his health as good or very good. Women were significantly more likely to report the two extreme categories very good or bad.
Table 3 reports selected ORs for age/sex versus selfrated health, and age and sex-adjusted ORs for further variables versus self-rated health as 'good' or better; more variables are reported in the online supplementary table 1. The OR for dichotomised self-rated health of men in relation to women was 0.89 . Furthermore, the OR declined strongly with age. Variables significantly associated with self-rated health in the expected direction were level of education, relocation experience, year of immigration, number of residential changes, feeling at home in Germany, German language skills, high blood pressure, obesity, frequent pain, limitation of mobility, employment status, feeling worn out, affected by family difficulties and stress at work or school. Affected by family difficulties during the last 4 weeks yielded a significant adjusted OR of 0.60 in the category 'not applicable', which mainly consisted of singles.

Table 4 contains the final multivariable model (model I) of dichotomised self-rated health as well as the model of the additional analysis (model II). The number of variables independently associated with self-rated health was considerably reduced in model I. In addition to age, marital status and education, different morbidities showed independent negative associations with good self-rated health. In model II, the variable experiencing frequent pain resulted in a very strong and highly significant independent effect, even though all missing information 
Table 3 Variables associated with self-rated health

Self-rated health in \% Less than good/bad

Overall $(n=595)$

Sex * $(n=592)$

Female
Male
Age $^{*}(n=583)$
$0-30$
$31-40$
$41-50$
$51-60$
$61-70$
$>70$

Level of education $\left(n=580, n_{\text {adj }}=571\right) \dagger$

Less than upper secondary school

Upper secondary school

47.2

37.4

62.6

5.1

12.3

36.5

23.5

17.0

5.8

61.3

22.3

University

16.4

44.1

55.9

$\leq 1994$

$>1994$

Feeling at home in Germany $\left(n=578, n_{\text {adj }}=569\right) \dagger$

$\begin{array}{lr}\text { Yes } & 47.4 \\ \text { Mostly } & 36.8 \\ \text { Sometimes } & 9.9 \\ \text { Not at all } & 5.9\end{array}$

German language skills $\left(n=590, n_{\text {adj }}=581\right) \dagger$

$\begin{array}{lrrr}\text { Very good } & 6.9 & 20.3 & 2.38(1.30 \text { to } 4.36) \\ \text { Good } & 59.9 & 56.6 & \text { reference } \\ \text { Less than good } & 23.7 & 20.9 & 0.96(0.62 \text { to } 1.49) \\ \text { Bad } & 9.7 & 2.6 & 0.21(0.08 \text { to } 0.58)\end{array}$

High blood pressure (Diagnosis/anti-hypertensive medication) $\left(n=587, n_{\text {adj }}=578\right) \ddagger$

$\begin{array}{ll}\text { No } & 27.2 \\ \text { Yes } & 72.8\end{array}$

72.8

66.6

33.4

52.3

21.9

25.8

48.9

51.1

53.3

38.9

5.9

2.0

OR adjusted

(95\% Cl)

52.3

40.2

reference

0.89 (0.64 to 1.24)

8.26 (4.04 to 16.89)

3.66 (2.16 to 6.20)

reference

1.04 (0.64 to 1.69)

0.65 (0.36 to 1.19)

0.55 (0.20 to 1.48$)$

Diabetes (diagnosis/anti-diabetic mediation) $\left(\mathrm{n}=587, \mathrm{n}_{\mathrm{adj}}=578\right) \dagger$

\begin{tabular}{|c|c|c|c|}
\hline No & 76.2 & 96.5 & reference \\
\hline Yes & 23.8 & 3.6 & $0.20(0.10$ to 0.40$)$ \\
\hline \multicolumn{4}{|c|}{ Obese $(B M I \geq 30)\left(n=550, n_{a d j}=542\right)$} \\
\hline Yes & 47.8 & 22.0 & $0.38(0.26$ to 0.57$)$ \\
\hline
\end{tabular}

Frequent pain $\left(n=520, n_{a d j}=514\right) \ddagger$

$\begin{array}{lrrr}\text { No } & 30.4 & 87.5 & \text { reference } \\ \text { Yes } & 69.7 & 12.6 & 0.06(0.03 \text { to } 0.93) \\ \text { Strong limitation of mobility }\left(\mathrm{n}=576, \mathrm{n}_{\text {adj }}=567\right) \dagger & & \text { reference } \\ \text { No } & 68.3 & 98.7 & 0.03(0.01 \text { to } 0.10) \\ \text { Yes } & 31.8 & 1.3 & \end{array}$

Continued 
Table 3 Continued

$\begin{array}{ll}\text { Self-rated health in \% } & \begin{array}{l}\text { OR adjusted } \\ \text { (95\% Cl) }\end{array}\end{array}$

\begin{tabular}{|c|c|c|c|}
\hline \multicolumn{4}{|c|}{ Employment status $\left(\mathrm{n}=590, \mathrm{n}_{\mathrm{adj}}=581, \mathrm{n}_{\mathrm{adj}}=538\right) \ddagger$} \\
\hline Employed & 40.7 & 64.2 & reference \\
\hline Pension & 39.3 & 14.8 & $0.56(0.34$ to 0.90$)$ \\
\hline Unemployed & 9.6 & 5.8 & $0.38(0.19$ to 0.76$)$ \\
\hline Other & 10.4 & 15.2 & $0.56(0.30$ to 1.02$)$ \\
\hline \multicolumn{4}{|c|}{ Feeling often worn out $\left(n=547, n_{\text {adj }}=538\right) \dagger$} \\
\hline No & 61.3 & 91.1 & reference \\
\hline Yes & 38.7 & 8.9 & $0.12(0.07$ to 0.21$)$ \\
\hline \multicolumn{4}{|c|}{ Never/rarely feeling full of energy $\left(n=525, n_{\text {adj }}=516\right) \neq$} \\
\hline No & 42.8 & 86.2 & reference \\
\hline Yes & 57.2 & 13.8 & $0.13(0.08$ to 0.20$)$ \\
\hline \multicolumn{4}{|c|}{ Affected by family difficulties (during last 4 weeks) $\left(n=549, n_{\text {adj }}=540\right) \dagger$} \\
\hline No & 34.8 & 46.5 & reference \\
\hline Little & 22.4 & 27.4 & $0.66(0.41$ to 1.08$)$ \\
\hline Strong & 12.4 & 5.7 & $0.26(0.12$ to 0.53$)$ \\
\hline Not applicable & 30.4 & 20.4 & 0.60 (0.38 to 0.96$)$ \\
\hline \multicolumn{4}{|c|}{ Stress at work or school $\left(n=507, n_{a d j}=501\right) \dagger$} \\
\hline No & 13.9 & 27.5 & 2.04 (1.17 to 3.58$)$ \\
\hline Little & 32.9 & 39.2 & reference \\
\hline Strong & 20.4 & 15.5 & $0.45(0.25$ to 0.79$)$ \\
\hline Not applicable & 32.9 & 17.9 & 0.83 (0.49 to 1.39$)$ \\
\hline
\end{tabular}

Prevalence and ORs $(95 \% \mathrm{Cl})$, adjusted for sex and age (continuous).

${ }^{*}$ Crude OR.

†Age modelled non-linear as age ${ }^{-1}$ in the age-adjusted and sex-adjusted model.

$\ddagger$ Age modelled non-linear as age ${ }^{-2}$ in the age-adjusted and sex-adjusted model.

was replaced by not having pain, which should weaken the association (conservative approach). Furthermore, 'education' was removed by the backward selection algorithm in model II, yielding an increase in $\mathrm{R}^{2}$ from $32 \%$ to $43 \%$.

\section{DISCUSSION}

The results of this study confirm the strong link between measurable health conditions, social deprivation and selfrated health. Since self-rated health constitutes a predictor for premature mortality, the results of the multivariable analyses may help to identify specific subpopulations at particular risk of reduced life expectancy. Thus, most endangered are Aussiedler experiencing frequent pain, followed by individuals with limited mobility, those diagnosed with diabetes mellitus and those with high blood pressure. In particular, individuals suffering from a combination of several of these chronic conditions may be in extreme jeopardy.

Self-rated health is a strong predictor for premature mortality and widely applied in health status studies of different populations. ${ }^{12}{ }^{18-20}$ The interconnection of selfrated health and mortality is generally accepted but not quite comprehended. The accuracy of the information lies on one's subjective understanding and prioritisation of components. Social and biological pathways have an influence on individual consciousness influencing selfrating. Thus both biological and contextual factors play a role. ${ }^{12}$ Perlman and Bobak applied the concept of self-rated health in the Russia Longitudinal Monitoring Survey and confirmed its association with mortality in Russian populations. ${ }^{20}$

Overall, $52.3 \%$ of the Aussiedler specified their selfrated health as good or very good. A study of Lampert $e t$ $a l$. in 2013 based on the DEGS (German Health Interview and Examination Survey for Adults) survey reported a prevalence of self-rated health as good or very good of $74.7 \%$ among adults (18 to 79 years) in Germany. ${ }^{21} \mathrm{~A}$ simple comparison of both figures yields a poor health status of Aussiedler. However, most probably the concept of self-rated health is influenced by cultural constructs and backgrounds, hence, measurement invariance is present, 
Table 4 Multivariate models of variables associated with self-rated health

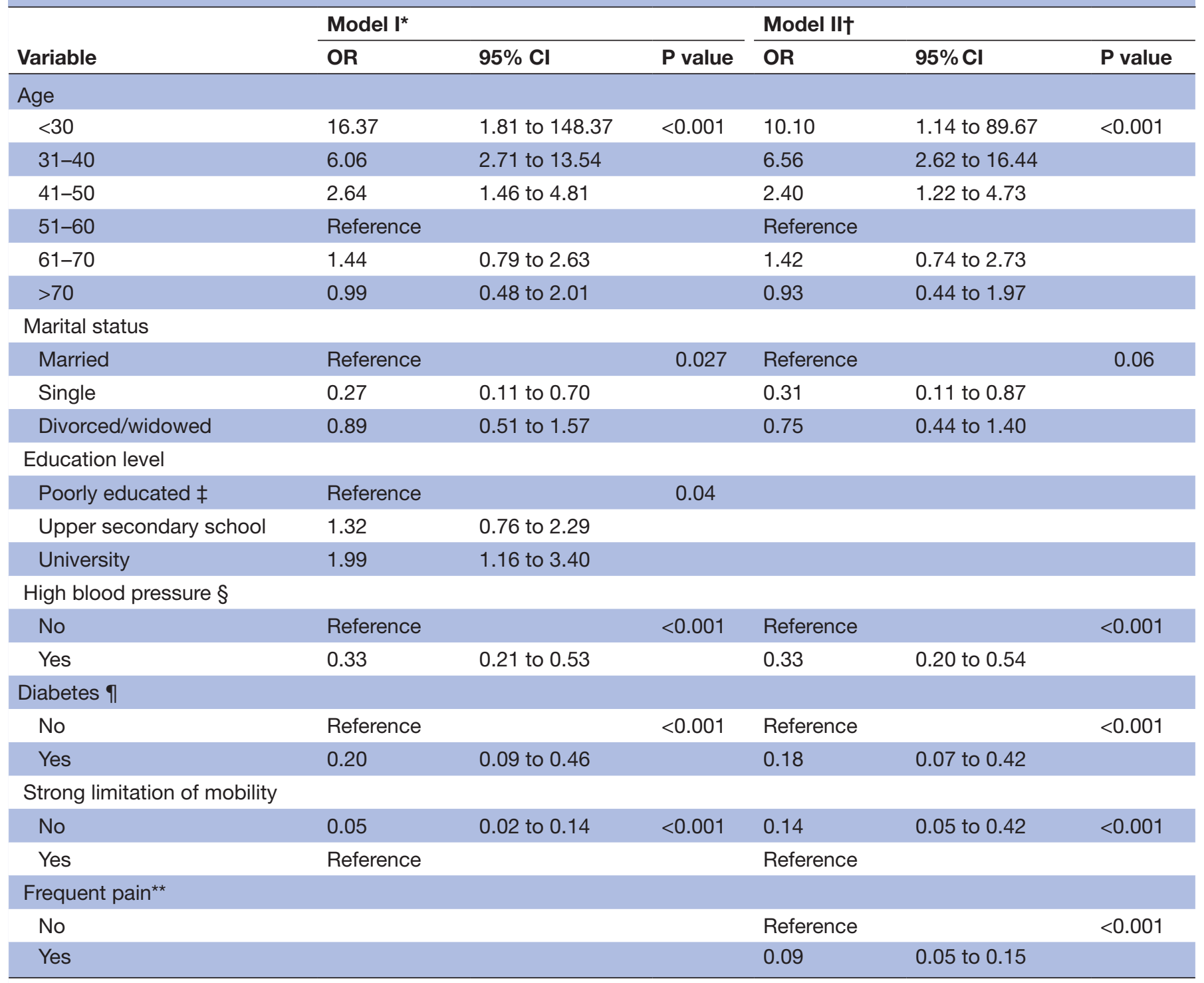

* $\mathrm{n}=550 ;$ McFadden's Pseudo $\mathrm{R}^{2}=0.32$.

$\dagger \mathrm{t}=557$; McFadden's Pseudo $\mathrm{R}^{2}=0.43$.

$\ddagger$ No education or still studying or secondary school or vocational training or other.

§High blood pressure diagnosed by a physician or indicated by taking anti-hypertensive medication.

ๆDiabetes as diagnosed by a physician or indicated by taking anti-diabetic medication.

${ }^{* *}$ All missing information on frequent pain were set to no pain.

which disqualifies a direct comparison. ${ }^{22}{ }^{23}$ Thus, the poorer health status of Aussiedler has to be interpreted with caution, although the magnitude of the difference indicates a real disparity.

A similar disparity has already been identified by Aparicio $e t$ al. in the same study region 10 years earlier, using data from the KORA Survey 2000 (Cooperative Health Research in the Region of Augsburg). ${ }^{7}$ Aparicio et al. found significant differences in health status, healthcare use and health behaviour between ethnic German immigrants from Eastern European countries, including 73\% FSU Aussiedler, and the autochthonous German population. They concluded that Aussiedler should be considered as high-risk population, which should be targeted by specific public health programmes. Our findings, although 10 years later, even reveal a deteriorated situation. In consequence, this may indicate that public health programmes based on the finding of Aparicio et al. have not been put in place or are not working at all.

The results of our study are affected by limitations inherent in the cross-sectional study design, which force us to draw conclusions on causal relationships. Additionally, the information on morbidity was only self-reported and not backed by medical records. Thus the results are prone to be affected by recall bias and subjectivity. However, a subsample $(\mathrm{n}=188)$ of our cohort was medically examined in large detail shortly afterwards. The age-group specific proportions of people living with 
medically confirmed high blood pressure, diabetes and obesity were similar or even higher than in the presented study. ${ }^{24}$

Despite the great efforts to address potential participants, only $17 \%$ of the Aussiedler returned a completed questionnaire and a valid written consent. Given this low response, the study population is highly selective. The study's response was similar to the response of migrants in a feasibility study of the nationwide German National Cohort. ${ }^{25}$ In the latter as well as in our study more women than men participated. Analyses from other studies showed that non-responders had a lower education or social status, were less likely to be married, were more frequently unemployed and had higher mortality or morbidity rates. ${ }^{26}{ }^{27}$ To which extent this holds true for the Augsburg survey could not be determined. Nevertheless, there is reason to assume that the responders in this survey were healthier than the average Aussiedler. For instance, the unemployment rate in the cohort was 5.6\% among men and $8.8 \%$ in women, compared with $5.2 \%$ among men, and $5.7 \%$ among women in the general population, according to the microcensus $2011 .{ }^{28}$ Official figures reported an unemployment rate of 32\% among Aussiedler in 1993 and of $28.6 \%$ in 2004 in Bavaria (4.3 times higher than among Germans; civil servants excluded), compared with $14.9 \%$ among foreigners. ${ }^{1}{ }^{29}$ In 2010 the official unemployment rate among Aussiedler was $8.7 \%$, which is an improved figure but was still higher than in the general population. However, their average net income was $€ 1428$, compared with $€ 1482$ among foreigners, and $€ 1741$ among persons without migration background. ${ }^{28}$ Additionally, the proportion of well-educated participants was higher than in the general public. In an evaluation of the microcensus data from 2005, the Aussiedler's education level was comparable to the general population. ${ }^{30}$ Furthermore, Aussiedler not feeling integrated might have been less willing to participate in our study, which was initiated by a German institution. Mistrust in institutions and to formally sign the informed consent seemed to be a huge barrier for non-responders, since $13.1 \%$ of the respondents returning the completed questionnaires did not affix their signature. In light of this selection, the findings are even more alarming. If this healthier subpopulation already contains $52.1 \%$ of individuals with a history of high blood pressure, 13.1\% with diabetes mellitus, $34.5 \%$ obese people, $40.7 \%$ of the individuals suffering from frequent pain and $15.9 \%$ with impaired mobility, the situation of Aussiedler in general most probably is worse.

The prevalence of smoking was similar in both groups of self-rated health, but alcohol intake was more frequently associated with good self-rated health $(84 \%$ vs. $71 \%)$. This finding may suggest a cultural perception of illness and socialisation patterns of alcohol having an effect on psychosocial factors influencing health of an individual. Perlman and Bobak showed that self-rated health among Russians was not influenced by morbidity only. Russian men reported more often good health, irrespective of their risky lifestyle. ${ }^{20}$ Similar mechanisms may have been present in the Augsburg study population, at least in ethnically mixed families. In fact, after adjusting for age and sex, the positive effect of alcohol on self-rated health disappeared. In the multivariable models neither alcohol nor smoking played a role.

The self-rated health of Aussiedler immigrating as youth was better than of persons immigrating in older ages. In particular, immigrating in the age of 11 to 20 years seemed to have a positive effect on self-rated health. This finding contradicts the significantly higher suicide rate among Aussiedler immigrating to Augsburg region in their puberty. ${ }^{10}$ however, the finding might be highly influenced by the present selection bias and a possible 'harvesting effect'. However, we omitted age at immigration in the final multivariable models due to the high correlation between age at immigration and current age. Further analyses might be needed to investigate the unbiased self-rated health especially among Aussiedler who immigrated in their youth and faced additional challenges owing to their specific phase of life.

Aussiedler are a subgroup of the German population with a unique history. Their experiences in their former countries, their way of living and the difficult process of integration constitutes a specific subset of factors that influences their objective and subjective health. Overall, our study could not report any improvement of the health status of Aussiedler 10 years after the first assessment. ${ }^{7}$ In contrary, their health situation seems to worsen. Another recent study observing cancer diagnosis with advanced tumour stages confirmed lower healthcare usage of Aussiedler. ${ }^{31}$

The model for good self-rated health shows that morbidity is the most influential factor-even in the most likely presence of selection bias towards a healthy cohort. Feeling exhausted and the impact of stress within the family further play a major role in generating subjective health, thus strengthening of emotional resources seems to be needed. Permanent stressors can be present in minority groups over the life course and even over generations, resulting in health gaps between advantaged and disadvantaged groups. ${ }^{32}$ In pursuit of reducing permanent stressors among the Aussiedler, public health authorities should provide tailored health counselling in order to strengthen their sense of coherence, mastery and social support.

\section{Author affiliations}

${ }^{1}$ Center of Clinical Epidemiology, University Hospital of Essen, Essen, Germany ${ }^{2}$ Institute for Technical Chemistry, Leibniz University Hannover, Hannover, Hannover ${ }^{3}$ Institute of Public Health, Unit Epidemiology and Biostatistics (EpiStat), University Hospital Heidelberg, Heidelberg, Germany

${ }^{4}$ Ludwig-Maximilians-Universität München, University Center for Health Sciences at the Klinikum Augsburg (UNIKA-T), Augsburg, Germany

${ }^{5}$ Institute of Medical Biometry and Epidemiology, University Hospital Hamburg Eppendorf, Hamburg, Germany

${ }^{6}$ Institute of Epidemiology, Helmholtz Zentrum München, German Research Center of Environmental Health, Neuherberg, Germany 
Acknowledgements We want to thank all those who participated in our survey and were willing to share their data with us. Especially we are grateful for the support from the officials from the Aussiedler organization (Landsmannschaft der Deutschen aus Russland e.V.) who were actively involved in our recruitment activities. Native speaker Sudtiffe Robynne kindly proofread the manuscript and checked the wording and English grammar. We acknowledge support by the Open Access Publication Fund of the University of Duisburg-Essen.

Contributors $\mathrm{HB}, \mathrm{CM}$ and $\mathrm{AD}$ conceived the study and collected the data. SSt cleaned the data. SSt and MO performed the analysis and drafted the paper. VW and $A D$ supported and enhanced the analyses and finalised the paper. All authors contributed to writing the manuscript and read and approved the final version.

Funding This work was supported by grants of the German Research Foundation (project numbers BE 2056/9-1,ME 3199/2-1) within the Graduate College 793: 'Epidemiology of communicable and chronic non-communicable diseases and their interrelationships'. The KORA research platform was initiated and financed by the Helmholtz Zentrum München, German Research Center for Environmental Health, which is funded by the German Federal Ministry of Education, Science, Research and Technology and by the State of Bavaria.

Competing interests HB was supported by the German Federal Ministry of Education and Research (grant number 01ER1306 PERGOLA).

Patient consent Obtained.

Ethics approval Ethics committee of the medical association of Bavaria.

Provenance and peer review Not commissioned; externally peer reviewed.

Data sharing statement No unpublished data from the study are available.

Open access This is an open access article distributed in accordance with the Creative Commons Attribution Non Commercial (CC BY-NC 4.0) license, which permits others to distribute, remix, adapt, build upon this work non-commercially, and license their derivative works on different terms, provided the original work is properly cited, appropriate credit is given, any changes made indicated, and the use is non-commercial. See: http://creativecommons.org/licenses/by-nc/4.0/.

\section{REFERENCES}

1. Westphal M. Familiäre und berufliche Orientierungen von Aussiedlerinnen. dlfMuiSIdU O, ed. Aussiedler: Deutsche Einwanderer aus Osteuropa. Osnabrück, 1999:127-49.

2. Deckert A. Myocardial infarction incidence, cardiovascular disease, and external cause mortality pattern among German repatriates: the impact of factual circumstances. In Press. 2013.

3. Deckert A, Winkler V, Meisinger C, et al. Myocardial infarction incidence and ischemic heart disease mortality: overall and trend results in repatriates, Germany. Eur J Public Health 2014;24:127-33.

4. Becher $\mathrm{H}$, Razum O, Kyobutungi $\mathrm{C}$, et al. Mortality of immigrants from the Former Soviet Union: Results of a cohort study. Dtsch Ärzteblatt 2007;104:1655-61.

5. Ronellenfitsch $\mathrm{U}$, Kyobutungi $\mathrm{C}$, Becher $\mathrm{H}$, et al. All-cause and cardiovascular mortality among ethnic German immigrants from the Former Soviet Union: a cohort study. BMC Public Health 2006;6:16.

6. Kuhrs E, Winkler V, Becher H. Risk factors for cardiovascular and cerebrovascular diseases among ethnic Germans from the former Soviet Union: results of a nested case-control study. BMC Public Health 2012;12:190.

7. Aparicio ML, Döring A, Mielck A, et al. [Differences between Eastern European immigrants of German origin and the rest of the German population in health status, health care use and health behaviour: a comparative study using data from the KORA-Survey 2000]. Soz Praventivmed 2005;50:107-18.

8. Volodina A, Bertsche T, Kostev K, et al. Drug utilization patterns and reported health status in ethnic German migrants (Aussiedler) in Germany: a cross-sectional study. BMC Public Health 2011;11:509.

9. Winkler V, Ott JJ, Holleczek B, et al. Cancer profile of migrants from the Former Soviet Union in Germany: incidence and mortality. Cancer Causes Control 2009;20:1873-9.
10. Deckert A, Winkler V, Meisinger C, et al. Suicide and external mortality pattern in a cohort of migrants from the former Soviet Union to Germany. J Psychiatr Res 2015;63:36-42.

11. Deckert A, Meisinger C, Heier M, et al, 2012.

Rekrutierungsmaßnahmen nahmen beim Aufbau einer prospektiven Kohorte von Aussiedlern aus der ehemaligen Sowjetunion in Augsburg. Presentation at the 7th Annual Conference of the German Society of Epidemiology, Augsburg.

12. Jylhä M. What is self-rated health and why does it predict mortality? Towards a unified conceptual model. Soc Sci Med 2009;69:307-16.

13. Franks P, Campbell TL, Shields CG. Social relationships and health: the relative roles of family functioning and social support. Soc Sci Med 1992;34:779-88.

14. Spallek J, Zeeb H, Razum O. What do we have to know from migrants' past exposures to understand their health status? a life course approach. Emerg Themes Epidemiol 2011;8:6.

15. Umberson D, Crosnoe R, Reczek C. Social relationships and health behavior across life course. Annu Rev Sociol 2010;36:139-57.

16. Allison PD. Measures of Fit for Logistic Regression. Support.SAS. com, Paper 1485-2014. https://support.sas.com/resources/papers/ proceedings14/1485-2014.pdf

17. Long JS, Freese J. Regression Models for Categorical Dependent Variables Using Stata. 3rd edn. College station, Texas: Stata Press, 2014:589.

18. Mossey JM, Shapiro E. Self-rated health: a predictor of mortality among the elderly. American Journal of 14. Public Health 1982;72:800-8.

19. Nielsen SS, Krasnik A. Poorer self-perceived health among migrants and ethnic minorities versus the majority population in Europe: a systematic review. Int J Public Health 2010;55:357-71.

20. Perlman F, Bobak M. Determinants of self rated health and mortality in Russia - are they the same? Int $J$ Equity Health 2008;7:19.

21. Lampert T, Kroll LE, von der Lippe E, et al. [Socioeconomic status and health: results of the German Health Interview and Examination Survey for Adults (DEGS1)]. Bundesgesundheitsblatt Gesundheitsforschung Gesundheitsschutz 2013;56:814-21.

22. Franks P, Gold MR, Fiscella K. Sociodemographics, self-rated health, and mortality in the US. Soc Sci Med 2003;56:2505-14.

23. Vandenberg RJ, Lance CE. A review and synthesis of the measurement invariance literature: suggestions, practices, and recommendations for organizational research. Organ Res Methods 2000;3:4-70.

24. Deckert A, Meisinger C, Becher H, et al, 2015. Anthropometrische Merkmale und Risikofaktoren für Herz-Kreislauf-Erkrankungen in einer Kohorte von Aussiedlern in Augsburg. Annual conference of the German Society for Epidemiology, Ulm.

25. Winkler V, Leitzmann M, Obi N, et al. Response in individuals with and without foreign background and application to the National Cohort in Germany: which factors have an effect? Int J Public Health 2014;59:555-63.

26. Langhammer A, Krokstad S, Romundstad P, Hveem K, et al. The HUNT study: participation is associated with survival and depends on socioeconomic status, diseases and symptoms. BMC Med Res Methodol 2012;12:143.

27. Galea S, Tracy M. Participation rates in epidemiologic studies. Ann Epidemiol 2007;17:643-53.

28. Destatis SB. [Population and Employment] Wiesbaden: Statistisches Bundesamt (Destatis). 2010. Contract No.: 2010220107004.

29. Brück-Klingberg $A$, Burkert $C$, Seibert $H$, et al. Spätaussiedler mit höherer Bildung sind öfter arbeitslos: IAB-Kurzberichte, Institut für Arbeitsmarkt- und Berufsforschung, 2007.

30. Kreft D, Doblhammer G. Individual and contextual determinants of health among Aussiedler and native Germans in the year 2005. Rostock, 2011.

31. Cho AB, Jaehn P, Holleczek B, et al. Stage of cancer diagnoses among migrants from the former Soviet Union in comparison to the German population - are diagnoses among migrants delayed? BMC Public Health 2018;18:148.

32. Thoits PA, Stress TPA. Stress and health: major findings and policy implications. J Health Soc Behav 2010;51 Suppl:S41-S53. 
Correction: Self-rated health among migrants from the former Soviet Union in Germany: a cross-sectional study

Stolpe S, Ouma M, Winkler V, et al. Self-rated health among migrants from the former Soviet Union in Germany: a cross-sectional study. BMJ Open 2018;8:e22947. doi: 10.1136/bmjopen-2018-022947.

This article was previously published with an error in the affiliations.

Affiliation number 3 should be:

Heidelberg Institute of Global Health, Unit Epidemiology and Biostatistics (EpiStat), University Hospital Heidelberg, Heidelberg, Germany.

Affiliation number 4 should be:

Chair for Epidemiology, Ludwig-Maximilians-Universität München at UNIKA-T Augsburg, Augsburg, Germany.

Co-author Andreas Deckert is associated to affiliation number 3.

Co-author Christa Meisinger is associated to affiliations 4 and 6.

Open access This is an open access article distributed in accordance with the Creative Commons Attribution Non Commercial (CC BY-NC 4.0) license, which permits others to distribute, remix, adapt, build upon this work non-commercially, and license their derivative works on different terms, provided the original work is properly cited, appropriate credit is given, any changes made indicated, and the use is non-commercial. See: http://creativecommons.org/licenses/by-nc/4.0/.

(c) Author(s) (or their employer(s)) 2018. Re-use permitted under CC BY-NC. No commercial re-use. See rights and permissions. Published by BMJ.

BMJ Open 2018;8:e022947corr1. doi:10.1136/bmjopen-2018-022947corr1

Check for updates 